\title{
NOTICE \\ International Conferences on Environmental Future
}

$\mathrm{H}$ aving held the First of these in 1971 and the Second in 1977, but then suffered the disappointment of abandonment of a long-planned Third when the expected host country dropped out 'at the last moment' inter alia as the main theme was being adopted elsewhere, it is gratifying to announce resumption of the series to the extent that a small Third ICEF is now planned for September 1987-as a lead-in to a Fourth, major event in the series, which it is hoped to organize for mid-1989 if not before.

The (first) International Conference on Environmental Future was sponsored by the Government of Finland and other Finnish interests, and took place in Helsinki and the University of Jyväskylä, Finland, during 27 June to 3 July 1971, providing many inputs to the United Nations 'Stockholm' Conference on the Human Environment which was held a year later. It led to numerous publications including the proceedings book cited first below.

The Second of the International Conferences on Environmental Future-then as now sub-entitled 'The Independent Forum for Global Survival' - was invited and sponsored by the Government of Iceland and was held in the Hotel Loftleidir, Reykjavik, in June 1977. It, too, led to many publications-including the second proceedings book cited below.

The 3rd ICEF is now replanned as a concentrated, invitatory affair sponsored by the Foundation for Environmental Conservation and the University of Edinburgh, Scotland - to mark the retirement of their Principal and Vice-Chancellor, Sir John Burnett, incidentally to become the first Executive Secretary of the World Council For The Biosphere. Planned by a special ad hoc Steering Committee, the Conference is due to take place in Edinburgh on 25 and 26 September 1987, and is to have the following programme (in outline):

\section{3rd ICEF: MAINTENANCE OF THE BIOSPHERE}

1. The Global System of Nature and the World Stage of Man

(a) Evolution of The Biosphere and the Ascent of Industrial Man

(b) The World Stage of Modern Man: Need for Stability with Diversity

2. The Biosphere in Transition
(a) The Sources of Change
(b) Their Effects and Interactions

3. Global Priorities
(a) Sustaining Basic Physicochemical and Climatic Systems
(b) Maintaining Ecological Productivity and Genetical Diversity

4. The Attainable Ideal in Human and Ecological Terms
(a) Moral Thrusts
(b) Biological Realities

\section{Practical Targets for Sustainability and Development}

(1 leading and 3 or 4 other commentators)

This 3rd ICEF is regarded (in addition to the personal reason already stated) partly as a much-needed international forum to discuss the vital theme indicated in its title-as well as many allied topics-and partly as a lead-in to the 4th ICEF, on the subject and with the probable title of 'Threats to The Biosphere'. It is expected that this will return to the category of much larger, 4 or 5 days' international gatherings invited and supported by national governments.

It is anticipated during the Conference to have the Second Baer-Huxley Memorial Lecture given by a leading international personality and to come out with an 'Edinburgh Imperative on Maintaining The Biosphere'.

Whereas participation in the Conference is strictly by invitation, there will be a public meeting and lunch-time discussion immediately following it at which leading exponents will speak and it is hoped the Edinburgh Imperative will be approved.

\begin{tabular}{|c|c|}
\hline $\begin{array}{l}\text { Nicholas Polunin, Secretary-General \& Editor } \\
\text { International Conferences on Environmental Future } \\
7 \text { Chemin Taverney, } 1218 \text { Grand-Saconnex } \\
\text { Geneva, Switzerland, }\end{array}$ & $\begin{array}{l}\text { ULRICH E. LOENING, Director } \\
\text { University of Edinburgh } \\
\text { Centre for Human Ecology, } 15 \text { Buccleuch Place } \\
\text { Edinburgh EH8 } 9 L N, \text { Scotland, UK. }\end{array}$ \\
\hline
\end{tabular}
REFERENCES

The Environmental Future: Proceedings of the first International Conference on Environmental Future, held in Finland from 27 June to 3 July 1971, Edited by Nicholas Polunin. Macmillan, London \& Basingstoke, England, UK, and Barnes \& Noble, New York, NY, USA: pp. xiv + 660, illustr., 1972.

Growth Without Ecodisasters? Proceedings of the Second International Conference on Environmental Future (2nd ICEF), held in Reykjavik, Iceland, 5-11 June 1977, Edited by Nicholas PoluNiN. Macmillan, London \& Basingstoke, England, UK, and Halsted Press Division of John Wiley \& Sons, New York, NY, USA : xxvi +675 pp., illustr., 1980. 